\title{
Bitter Gourd and Pomegranate Seed Oils as Sources of $\alpha$-Eleostearic and Punicic Acids: Purification and II Antioxidant Properties in Cell Lines
}

\author{
Yoshime LT, Melo ILP, Sattler JAG and Mancini-Fillho J* \\ Food Science and Experimental Nutrition Department FCF, University of São Paulo, Brazil
}

Submission: March 20, 2018; Published: March 27, 2018

"Corresponding author: Jorge Mancini-Filho, Lipids Laboratory, Food Science and Experimental Nutrition Department. University of São Paulo, Brazil; Tel: (55 11) 30913656, Email: jmancini@usp.br

\begin{abstract}
The purification and the identification of the properties of the Conjugated Linolenic Acids (CLNAs) which ensued from the bitter gourd and pomegranate seed oils were both carefully accomplished. These calculated procedures were aimed at contributing to the elucidation of the mechanisms of action of these acids in different cell lines. The preliminary results have indicated positive effects of an inhibition of the oxidative processes by the CLNAs.

Keywords: Bitter Gourd; Pomegranate Seed Oils; $\alpha$-Eleostearic Acid; Punicic Acid

Abbreviations: CLNAs: Conjugated Linolenic Acids; BSO: Bitter Gourd; PSO: Pomegranate; ROS: Reactive Oxygen Species; HPLC: HighPerformance Liquid Chromatography
\end{abstract}

\section{Introduction}

The Conjugated Linolenic Acids (CLNAs) have been widely studied for their properties. They are associated with specific physiological effects, as has been shown by various in vivo studies. These conjugated linolenic acids are related to anticarcinogenic, anti-adipogenic, anti-inflammatory and antiatherosclerotic activities [1-3]. The CLNAs are rich in specific oils from seeds. These particular oils, which are now being currently studied herein, have evolved from Bitter Gourd (BSO) and Pomegranate (PSO) seeds. They present high concentrations of $\alpha$-eleostearic acid (C18:3-9c11t13t) and punicic acid (C18:39c11t13c), respectively [4,5]. The benefits of the CLNAs are seemingly associated with conjugated linoleic acid (CLA), as some studies have indicated that CLNA is converted to CLA in certain cells.

The roles of the CLNAs in antioxidant activities were investigated by Anusree, et al. [6]. In their study, a cell treatment with TNF- $\alpha$ caused significant alterations in their mitochondrial trans-membrane potential, with a reduction in their ATP production, their 02 consumption, together with an overall increase in their cellular Reactive Oxygen Species (ROS) generation. This present identification of the $\alpha$-eleostearic and punicic acids is in the initial stage of evaluating their properties in different tissues (Caco-2 and HepG2 cell cultures).
These particular cell lines can mimic the intestinal absorption, the incorporation and hepatic metabolism, as well as the functions of the CLNAs in the production of ROS [7]. This preliminary study has aimed at purifying and evaluating the antioxidant potential of the conjugated isomers from bitter gourd and pomegranate seed oils in different cell lines (Caco-2 and HepG2).

\section{Methods and Procedures}

The bitter gourds and the pomegranates were obtained commercially from the city of São Paulo, Brazil. Their seeds were extracted in order to separate their lipid fractions by a Soxhlet extractor, when using hexane as a solvent [4,5]. The oils were hydrolyzed as has already been described by Schneider et al., (2012). The isolation of the $\alpha$-eleostearic and punicic acids was performed by using the Semi-Preparative System. The confirmation of these components was conducted by HighPerformance Liquid Chromatography (HPLC), when coupled with a mass spectrometer [8]. The cell viabilities were executed with the CLNAs that were isolated from the BSO and PSO seeds, at different concentrations and with a 24 hours exposure. The detection of the ROS that was generated in the Caco2 and HepG2 cells in the presence of the CLNAs was performed by using a reaction with 2',7'-dichlorofluorescein diacetate. 


\section{Results}

The $\alpha$-eleostearic and punicic acid contents in the lipid fractions of the bitter gourd and pomegranate seeds were $63.54 \%$ and $85.25 \%$, respectively. These results confirmed the main components of the lipid fractions of these seeds. The cytotoxicity was calculated for the IC50 values from the dose-response curves. In the Caco- 2 cell line, the concentrations were $25.31 \mu \mathrm{M}$ (BSO) and $15.43 \mu \mathrm{M}$ (PSO), respectively. In the HepG2 cell line, they were $80.28 \mu \mathrm{M}$ (BSO) and $107.00 \mu \mathrm{M}$ (PSO), respectively. The reactive oxygen species (ROS) that were generated were statistically significantly $(\mathrm{p}<0.05)$. They were lower at $25 \mu \mathrm{M}$ of BSO, when compared to the basal group in the Caco 2 cell line. On the other hand, the HepG2 cell line generated higher ROS values, when compared to the basal group.

\section{Conclusion}

This study has confirmed the high presence of $\alpha$-eleostearic acid and punicic acid in the two seed oils (bitter gourd and pomegranate). As a result, they can be important sources for functional/nutraceutical industrial purposes. It was possible to identify the concentrations (IC50) for an evaluation of these CLNAs in the liver and in the intestinal cells. Moreover, the presence of BSO reduced the generation of ROS in the cell cultures. These results are part of a broad investigation into the antioxidant potentials of the CLNAs and new steps involving lipid peroxidation and the activities of the antioxidant enzymes will be performed. In evaluating the presence of the $\alpha$-eleostearic and punicic acids and their functionality in cell cultures, it may be contributing to the prevention of metabolic disorders which are related to an inhibition of the oxidative processes.

\section{Acknowledgement}

The authors would like to thank the FAPESP for their support that was granted through project No. 2016 / 14485-4.

\section{References}

1. Hennessy AA, Ross PR, Fitzgerald GF, Stanton C (2016) Sources and Bioactive Properties of Conjugated Dietary Fatty Acids. Lipids 51(4): 377-397.

2. Miranda J, Arias N, Fernández-Quintela A, del Puy Portillo M (2014) Are conjugated linolenic acid isomers an alternative to conjugated linoleic acid isomers in obesity prevention? Endocrinología Y Nutrición 61(4): 209-219.

3. Yuan G, Chen XE, Li D (2014) Conjugated linolenic acids and their bioactivities: a review. Food \& Function 5(7): 1360-1368.

4. Melo ILP De, Carvalho EBT De, Silva AM De, Yoshime LT, Sattler JAG, et al. (2016) Characterization of constituents, quality and stability of pomegranate seed oil (Punica granatum L.). Food Science and Technology (Campinas) 36(1): 132-139.

5. Yoshime LT, De Melo ILP, Sattler JAG, De Carvalho EBT, Mancini-Filho J (2016) Bitter gourd (Momordica charantia L.) seed oil as a naturally rich source of bioactive compounds for nutraceutical purposes. Nutrire 41(1): $1-12$.

6. Anusree SS, Nisha VM, Priyanka A, Raghu KG (2015) Insulin resistance by TNF- $\alpha$ is associated with mitochondrial dysfunction in 3T3-L1 adipocytes and is ameliorated by punicic acid, a PPAR $\gamma$ agonist. Molecular and Cellular Endocrinology 413: 120-128.

7. Schneider AC, Beguin P, Bourez S, Perfield JW, Mignolet E, et al. (2012) Conversion of t11t13 CLA into C9t11 CLA in Caco-2 cells and inhibition by sterculic oil. PLoS ONE 7(3): 7-14.

8. Mashhadi Z, Boeglin WE, Brash AR (2015) Robust inhibitory effects of conjugated linolenic acids on a cyclooxygenase-related linoleate 10S-dioxygenase: Comparison with COX-1 and COX-2. Biochimica et Biophysica Acta - Molecular and Cell Biology of Lipids 1851(10): 13461352.

\section{Your next submission with Juniper Publishers will reach you the below assets}

- Quality Editorial service

- Swift Peer Review

- Reprints availability

- E-prints Service

- Manuscript Podcast for convenient understanding

- Global attainment for your research

- Manuscript accessibility in different formats

( Pdf, E-pub, Full Text, Audio)

- Unceasing customer service

Track the below URL for one-step submission https://juniperpublishers.com/online-submission.php 